\title{
FINANCIAL PERFORMANCE OF ISLAMIC BANKING IN INDONESIA WITH MAQASID SHARIAH APPROACH
}

\author{
Rahmat Hidayat ${ }^{1}$, Yeni Oktaviani ${ }^{2}$, Aminudin ${ }^{3}$ \\ Ahmad Dahlan Institute of Technology and Business Jakarta \\ E-mail: yenioktavianiyunaz@gmail.com
}

\begin{abstract}
This research aims to demonstrate the financial performance of Islamic banking in Indonesia using the Maqasid al-Shariah approach. This study used Partial Least Square (PLS) to evaluate the relationship between the Maqasid alShariah concept and its indicators and linear regression to prove causality relationship between variables. The research objects were Bank Muamalat Indonesia (BMI), Bank BRI Syariah (BRIS), Bank BNI Syariah (BNIS), Bank Mandiri Syariah (BMS), Bank Panin Syariah (PBS), and Bank Mega Syariah Indonesia (BSMI). The results demonstrated that the indicator of research and development were the dominant indicators in the aspect of Tahdhib al-Fard (Individual Education) and had a contribution to ROE. However, the Tahdhib alFard aspect (Individual Education) did not affect ROA. The indicator of equitable development was the dominant indicator in the aspect of Iqamat al-Adl (building justice) and did not affect ROA; however, equitable and functional distribution of murabaha and musyarakah contributed to ROE. The indicator of real sector investment in the aspect of Jalb al-Maslahah (improving welfare) had a dominant formative contribution, and it contributed to ROE. The concept of Maqashid Shariah simultaneously affects $34.9 \%$ of ROA and $39.7 \%$ of ROE.
\end{abstract}

Keywords: maqasid shariah, financial performance, Islamic banking

\section{INTRODUCTION}

Measuring the performance of Islamic banks in terms of profitability is considered insufficient as a basis of Islamic banking advancement. Maqashid Shariah index is a measurement of the Islamic banking performance; however, the realization of Maqashid Shariah in Islamic banking is still poorly performed, as it is explained by Antonio (2012). Mohammed (as cited in Zahrah, 1997) states several elements of Maqashid Shariah which can be measured through quantitative methods or referred to as Maqashid Shariah index, namely the objective of tahdhid al-fard (private education), iqamat al-'adl (constructing justice), and Jalb alMaslahah (increasing welfare).

Abozaid and Dusuki (2007), Muhammad (2008), Ahmed (2011), Antonio (2012), Houssem (2012), Mansour (2013) claim that Maqashid Shariah is the concept of morality, ethics, and social values becoming a unity where these values contribute to improving the financial performance of Islamic banking. In other words, the higher the Maqashid Shariah of Islamic banking, the better the financial performance of Islamic banking. 
According to Hilary and Hui (2009), Burton and Goldsby (2010), and Mayew (2012), religious values such as ethics and morals have a positive relationship with the company's financial performance. Moreover, Adebayo (2013) explains Maqashid Shariah, which is based on Islamic values such as ethics, moral, and social in Islamic economics and as a measure of the performance of Islamic banking, is expected to create Islamic economic human (HomoIslamicus).

According to Asutay (2007), Islamic human beings have their characteristics; namely, they are economic human (Homo economicus) and also Islamic economic human where they act as an agent of care related to social justice and economic growth centered on human and development. Islamic banking should realize this potential as a distinct market segmentation in observing the Islamic banking market.

Furthermore, Setiawan (2009), Jahja (2012), and Wiranti (2014) claim that Islamic banking is banking that has two functions, namely social functions, and commercial functions. Accordingly, Islamic banking must be examined integrally and comprehensively related to its social performance and financial performance. Moreover, Sani Dangulbi (2012) asserts that Islamic banking performance measurement model has a unique characteristic that cannot be equated with the measurement of conventional banking performance. The measurement of Islamic banking performance must be measured by using a model which is compatible with the objectives of Islamic law, namely Maqashid Shariah.

The Maqashid Shariah concept, which is based on Islamic values namely: business ethics, religious morals, and corporate social performance, is in contrast to new classic economics that rejects corporate social responsibility. As Friedman (1970) in the monetarism theory states that business institutions have full responsibility to the shareholders and not to social responsibility, shared values and individual responsibility are the responsibility of the government and they are not a business responsibility, social responsibility undermines the principle of a free society foundation.

This monetarism theory is widely used by capitalist scholars such as McWilliams and Donald (2000), Mattingly (2004), Surroca and Trib (2008), Rowley and Berman (2010), and Yang (2010), who point out that the concept of social responsibility performance has no positive contribution to the company's financial performance.

Some researchers only measure the performance of Islamic banking in terms of the probability of banks and this is considered insufficient as a basis for Islamic banking advancement. Considering that Islamic banking is disparate from conventional banking in terms of theory and practice, a paradigm shift is needed in measuring the performance of Islamic banking by bringing up Maqashid Shariah as an assessment of the performance of Islamic legal values implementation. 


\section{LITERATURE REVIEW}

Abu Zahrah classifies the purpose of Maqashid Shariah, then it was developed by Muhammad Omar Mustafa by using the operational behavior approach method (Sakaran's Method) (Sakaran, 2000) to produce a measurable element to be the Maqashid Shariah index. The classification of Maqashid Shariah purposes is tahdhib al-fard (educating individuals), iqamat al'adl (building justice), and Jalb almaslahah (improving welfare) which were shown as "Concept (C)." Furthermore, it is developed into a broader characteristic called "Dimension (D)," a dimension which is further developed into measurable behavior namely "Element (E)."

The development of the Maqashid Shariah concept by Houssem (2012), which measures the Maqashid Shariah of al-Ghazali's thought as an interrelated entity, is by describing the spider network of the Maqashid Shariah Index framework. Furthermore, Habib Ahmad (2011) proposes the measurement of the Maqashid Shariah value through Islamic banking products by employing two assessment criteria, namely legal and social assessment. Both of these academics' thoughts are devoted to qualitative research as a descriptive study of Maqashid Shariah.

The operational behavior approach (Sakaran's Method) can be described in an example of "Thirsty" as a "Concept", the behavior of thirsty people is to drink lots of "Water" as "Dimension" and thirst levels can be measured by "Glass Amounts" of water which are drunk as "Element". The following is an overview of the Operational Behavior Approach (Sakaran's Method).

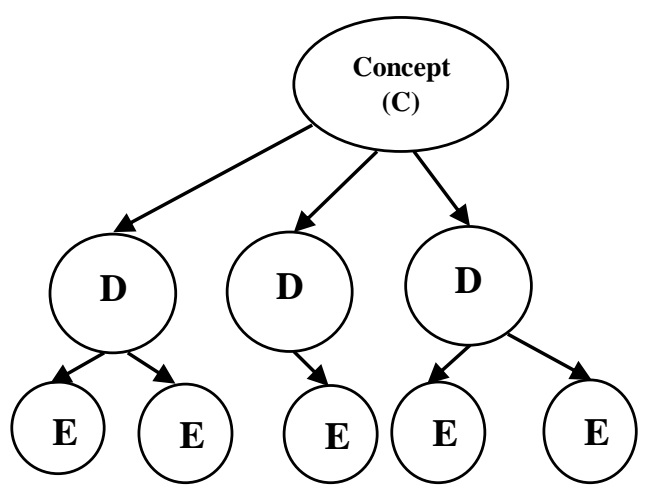

Figure 1. Sakaran's Method Source: Mohammed, et al., 2008

Hameed (2004) also develops the measurement of Maqashid Shariah with a quantitative approach called Islamicity index, the measured indicators are: 1) profit and sharing ratio, 2) zakah performance ratio, 3) equitable distribution ratio, 4) directors-employees welfare ratio, 5) Islamic investment vs. non-Islamic investment, 6) Islamic income vs. Non-Islamic income, 7) AAOIFI Index.

Furthermore, the classification of tahdhib al-fard (private education) includes four financial ratios namely; education grants/ratio of total income, research costs/ratio of total costs, training costs/ratio of total costs, and publication costs/ratio of the total cost. These ratios illustrate the higher the bank allocates costs for the four indicators of the ratio, the better the education program for human resources of the company; thus it can improve the expertise, skills, and accountability of the company's human resources. Accordingly, this can increase productivity and value-added which 
ultimately can contribute to the company's financial performance.

The ratio of funding for training, research, and educational grants in the tahdhib al-fard classification is included in corporate intellectual capital. Islamic banking, which is a knowledge-based business company, has not only the tangible assets but also the intangible assets. Therefore, it must pay attention to the intangible assets in order to improve the company's financial performance. Intellectual capital is collective knowledge, information, intellectual, experience, organizational learning and competence, communication systems, customer relations, and brands that can create corporate value (Thomas, 2002).

Maqashid Shariah index formulated by Mohammed, et al (2008) states that one of the ways for a company to achieve Maqashid Shariah is to increase tahdhib al-fard (individual education) by allocating the corporate finance for education, training, and research programs which is the responsibility of Islamic companies as a social responsibility to improve the skills and knowledge of the employees. This is the intangible capital as the intellectual capital of the company in order to increase value-added and productivity of company performance which will ultimately contribute positively to the performance of financial statements.

The classification of iqamat alladl (building justice) according to Mohammed et al. (2008) covers three financial ratios namely; equitable distribution (investment profit/total of investment income), functional distribution (Mudharabah and musharakah model/total of financing), and interest-free income/ratio of total income. Whereas according to Antonio et al. (2012), the iqamat al-ladl classification includes the ratio of profit equalization reserves (PER)/net or investment income, mudharabah and musharakah modes/total investment modes, and interest-free income/total income. These ratios describe that the Islamic banking justice principle is achieved if there are no disadvantaged stakeholders (customers and banks) and they are mutually beneficial.

The ratio of Profit Equalization Reserves (PER) or set aside income is a picture of injustice since the right of savers to receive profits has been postponed by the bank to anticipate losses. A fair distribution ratio by looking at the difference in investment profit division between customers and Islamic banking signifies the implementation of the Islamic banking justice principle for the investment process. The mudharabah and musharakah model ratio show that banks have a role in increasing social justice as a contract of the principle of profit and loss sharing (PLS).

Moreover, there are two financial ratios in the classification of Jalb al-maslahah (improving welfare) as follows; the ratio of zakat payment/net assets and the ratio of real sector investment/ investment total. The zakat ratio represents the obligation of Muslims to share and increase the welfare of the poor so that it can reduce economic inequality. Also, the ratio of investment deposits indicates that the 
banks place their funds in productive enterprises that move the real sector of the economy; hence, it has direct implications for society at large.

\section{METHODS}

This research used the Maqashid Shariah Index approach to measure the financial performance of Islamic banks. The Maqashid Shariah Index indicators consisted of private education, creating justice, and achieving public interest. The financial performance used indicators of Return on Assets (ROA) and Return on Equity (ROE).

Data analysis to test the relationship between the variables and its indicators was Partial Least Square Analysis. The objects of the research were Islamic Commercial Banks in Indonesia. The samples taken were six Islamic Commercial Banks (ICB), namely Bank Muamalat Indonesia (BMI), Bank BRI Syariah (BRIS), Bank BNI Syariah (BNIS), Bank Mandiri Syariah (BMS), Panin Bank Syariah (PBS), and Bank Mega Syariah Indonesia (BSMI). The data collection technique was in the form of published Islamic Commercial Bank financial statement documentation.

\section{RESULTS AND DISCUSSION}

The loading factor value of the indicator of Maqashid Shariah concept in Islamic banking would be shown in Table 1 below:

Table 1. Outer Loading of Maqashid Shariah Indicators in Islamic Banking in Indonesia

\begin{tabular}{|c|c|c|c|c|c|c|c|}
\hline \multirow{2}{*}{ Indicator } & \multirow{2}{*}{ Variable } & \multicolumn{6}{|c|}{ Standardized Loading Factor } \\
\hline & & 2010 & 2011 & 2012 & 2013 & 2014 & 2015 \\
\hline i1x1 & & 0.8519 & $0.4715^{*}$ & 0.6289 & $-0.0672^{*}$ & 0.8670 & $0.2763^{*}$ \\
\hline $\mathrm{i} 2 \mathrm{x} 1$ & Tahdhib al-Fard (X1) & 0.7656 & 0.8013 & 0.9395 & 0.9864 & $0.2096^{*}$ & $-0.7622^{*}$ \\
\hline $\mathrm{i} 3 \mathrm{x} 1$ & & 0.5907 & 0.6889 & 0.5441 & $0.4200^{*}$ & 0.9460 & 0.7768 \\
\hline i1 $x 2$ & & 0.6704 & 0.9394 & 0.9183 & 0.8876 & 0.9624 & 0.9904 \\
\hline $\mathrm{i} 2 \times 2$ & Iqamat al- $\mathrm{Adl}(\mathrm{X} 2)$ & 0.8998 & $-0.0708^{*}$ & 0.8132 & 0.9519 & 0.9800 & 0.9614 \\
\hline i1 $1 \times 3$ & Jalb al-Maslahah & 0.8892 & 0.6253 & 0.7853 & $0.015^{*}$ & 0.9811 & 0.8808 \\
\hline $\mathrm{i} 2 \times 3$ & $(\mathrm{X} 3)$ & 0.8449 & $-0.7195^{*}$ & 0.9935 & 0.7499 & 0.9833 & 0.9697 \\
\hline ROA & Financial Performance & 0.9715 & 0.9809 & 0.8128 & 0.9407 & 0.9532 & 0.9605 \\
\hline ROE & $(\mathrm{Y})$ & 0.9638 & 0.7642 & 0.9403 & 0.9536 & 0.9577 & 0.9689 \\
\hline
\end{tabular}

The loading factor results of The Maqashid Shariah indicator in Islamic banking showed that in 2010 and 2012, all indicators had loading factor values of above 0.5 , meaning that all indicators were declared valid. However, in 2011, there were indicators declared invalid, namely indicator of "allocation of education and training fund (i1x1)" in the aspect of Tahdhib al-Fard (X1), indicator of "affordable products and services (i2x2)" in the aspect of Iqamat al-'Adl (X2), an indicator of "Real sector investment (i2x3)" in the aspect of Jalb al-Maslahah (X3).

Furthermore, in 2013, three indicators were claimed invalid, that was the indicator of "education and training fund allocation (i1x1)", the indicator of "socialization fund allocation (Advertisements) (i2x1)", and the indicator of "property distribution (zakat) (i1x3)". In the 
following year, one indicator in the aspect of Tahdhib al-Fard (X1), namely the indicator of "allocation of research and development fund (i1x1)" did not have a valid loading factor value. Moreover, in 2015 there were two invalid indicators of the measurement of the Tahdhib al-Fard (X1) aspect, namely the indicator of "education and training fund allocation (i1x1)" and "research and development fund allocation (i1x1)". This mean that the relationship between the indicator of "education and training fund allocation" of Islamic banking and the Tahdhib alFard variable was not well validated, therefore, as a reflective model, it would be excluded from the constructed model.

Table 2. Composite Reliability of Maqashid Shariah in Islamic Banking in Indonesia

\begin{tabular}{lcccccc}
\hline \multirow{2}{*}{ Variable } & \multicolumn{6}{c}{ Composite Reliability } \\
\cline { 2 - 7 } & 2010 & 2011 & 2012 & 2013 & 2014 & 2015 \\
\hline Tahdhib al-Fard (X1) & $0.6408^{*}$ & $0.6985^{*}$ & 0.7579 & $0.4928^{*}$ & 0.7575 & $0.0464^{*}$ \\
Iqamat al- Adl (X2) & 0.7689 & $0.4042^{*}$ & 0.8581 & 0.9171 & 0.9708 & 0.9757 \\
Jalb al-Maslahah (X3) & 0.8586 & $0.0081^{*}$ & 0.8887 & $0.2895^{*}$ & 0.9821 & 0.9234 \\
Financial Performance (Y) & 0.9671 & 0.8703 & 0.8710 & 0.9458 & 0.9545 & 0.9641 \\
\hline
\end{tabular}

Table 2 showed the composite reliability of Maqashid Shariah in Islamic banking in Indonesia. The table revealed that the aspect of Tahdhib al-Fard (X1) in 2010, and all aspects of Maqashid Shariah in 2011 had composite reliability values under the criteria of 0.70 ; thus they were not reliable. Furthermore, In 2012 and 2014, the achievement of composite reliability value of all aspects of Maqashid Shariah was declared reliable.

In addition, Tahdhib al-Fard (X1) and Jalb al-Maslahah (X3) aspect in 2013 and 2015 had composite reliability values under the criteria of 0.70 . From these results, it could be concluded that in the Maqashid Shariah reflective model evaluation, there was an indicator claimed invalid, namely the indicator of "education and training fund allocation (i1x1)". This indicator was one of the measuring instruments for the aspect of Tahdhib al-Fard (X1). In addition, in the reliability analysis, the Tahdhib alFard (X1) aspect was also stated to be unreliable as a measurement instrument of the reflective model of the Maqashid Shariah concept. The aspect of Jalb al-Maslahah (X3) was also regarded to be unreliable due to the deficient data validity result for the indicator of "real sector investment (i2X3)". The two indicators in the reflection model evaluation would be excluded from the construct of the Maqashid Shariah concept and could not be used in the next hypothesis. 
Table 3. T Statistic Table of Outer Weight of Maqashid Shariah Concept

\begin{tabular}{lllllll}
\hline \multirow{2}{*}{ Correlation } & \multicolumn{6}{c}{ T Statistics $(|\mathrm{O} / \mathrm{STERR}|)$} \\
\cline { 2 - 7 } & \multicolumn{1}{c}{2010} & \multicolumn{1}{c}{2011} & 2012 & \multicolumn{1}{c}{2013} & \multicolumn{1}{c}{2014} & \multicolumn{1}{c}{2015} \\
\hline i1X1 => Tahdhib al-Fard & 4.8113 & $1.1164^{*}$ & 2.5652 & 3.2858 & 35.8166 & $0.4576^{*}$ \\
i2X1 => Tahdhib al-Fard & 5.7550 & 3.3760 & 9.5053 & 30.3032 & 3.6026 & $0.9985^{*}$ \\
i3X1 => Tahdhib al-Fard & 16.8613 & 1.6475 & 2.7782 & 7.0781 & 28.2958 & $1.0297^{*}$ \\
i1X2 => Iqamat al-adl & 1.6754 & 26.3346 & 18.2485 & 52.3437 & 9.2616 & 1.6418 \\
i2X2 => Iqamat al-adl & 43.7454 & 5.2354 & 18.6023 & 37.2672 & 12.0835 & $0.7063^{*}$ \\
i1X3 => Jalb al-Maslahah & 9.6995 & 2.2548 & 1.6564 & 3.4970 & $1.3378^{*}$ & $1.0286^{*}$ \\
i2X3 => Jalb al-Maslahah & 15.8761 & 1.8302 & 1.7007 & 8.4844 & $1.3913^{*}$ & 1.7051 \\
ROA => Financial Performance & 16.9277 & 26.0155 & 3.1704 & 3.9118 & 2.0879 & $1.0659^{*}$ \\
ROE => Financial Performance & 3.7000 & 6.2293 & 1.6901 & 27.4873 & $1.4923^{*}$ & $1.0593^{*}$ \\
\hline
\end{tabular}

The research result in Table 3 showed the value of $t$ statistics of all indicators toward the Maqashid Shariah latent variable in 2010, 2012 and 2013 were valid. In 2011, there was one invalid indicator, namely the indicator of "education and training fund allocation (i1x1)" in the aspect of Tahdhib al-Fard. In 2014, two aspects of Jalb al-Maslahah, namely property distribution (zakat) (i1x3) and real sector investment (i2x3), had $\mathrm{t}$ statistic values under $1.64 \mathrm{t}$ table and were declared invalid. Moreover, in 2015 there were seven invalid indicators and two reliable indicators, namely the indicator of "fair distribution assessment (i1x2)" in the aspect of Iqamat al-Adl and indicator of "real sector investment (i2x3)" in the aspect of Jalb alMaslahah.

Some research related to the Maqashid Shariah Index indicator was Muhammad, et al. (2008) and Antonio, et al. (2012), who stated that to measure the Maqashid Shariah Index, the indicators were the indicators of education and training, research and development as well as public outreach for the Tahdhib al-Fard variable. For the variable of Iqamat al- 'Adl Indicator, the indicators were equitable distribution, functional distribution (Mudharabah and Musharakah model,) and the elimination of usury elements. In addition, the zakat fund income and real sector investment were the indicators to measure the Jalb al-Maslahah variable. However, this research did not test the indicator of "usury elements elimination" since the indicator did not have a testable value. This meant that Islamic banking did not include usury income into its financial performance; thus the indicator was irrelevant to be tested in this research.

From the above result discussion, it could be concluded that the Maqashid Shariah Index and its indicators could be empirically proven through a formative model. The Maqashid Shariah Index concept was an idea from Muhammad, et al. (2008). It was first described in a qualitative approach that had not been empirically proven using a quantitative approach. Accordingly, the verification in this research could be the basis for quantitative measurement of the Maqashid Shariah Index performance in Islamic banking. 
The result of simultaneously and partially regression test analysis of the Maqashid Shariah concept contribution to Return on Assets (ROA) financial performance of Islamic banking in Indonesia for the 2010-2015 period was the value of $F$ count of 2.141. This value was higher than the value of $\mathrm{F}$ table, which meant that Ho was rejected and $\mathrm{Ha}$ was accepted with the hypothesis that there was a contribution of the Tahdhib al-Fard, Iqamat al-Adl, and Jalb al-Maslahah variable simultaneously to the Return on Assets (ROA) performance of Islamic banking.

The result of data analysis showed that the Tahdhib al-Fard variable indicator had $\mathrm{t}$ count value lower than the $t$ table value. Accordingly, it could be concluded that Ho was accepted and $\mathrm{Ha}$ was rejected with the hypothesis that there was no partial contribution of Tahdhib al-Fard variable Indicator to Return on Asset (ROA) performance of Islamic banking. Additionally, the Iqamat al-Adl variable indicator also had $t$ count value lower than the $t$ table value; therefore, it could be interpreted that the Iqamat al-Adl variable did not have any contribution to the Return on Assets (ROA) performance of Islamic banking partially.

However, there was one indicator of the Jalb al-Maslahah variable with the value of $t$ count higher than the value of t table with the hypothesis that the Jalb alMaslahah variable indicator had a positive contribution to the performance of Return on Assets (ROA) of Islamic banking partially. The indicator was the indicator of "real sector investment (i2x3)" with a significance value of 0.004 .

The determination coefficient of the Maqashid Shariah concept on the Sharia Commercial Banks Return on Assets (ROA) performance was the R Square value of 0.349 (34.9\%). This result described that the performance of Return on Assets (ROA) of Islamic banking could be explained by the Maqashid Shariah concept, namely the Tahdhib alFard, Iqamat al-Adl, and Jalb alMaslahah variable, which is $34.9 \%$. In addition, this also meant that there were around $66.1 \%(100 \%-34.9 \%)$ explained by other variables outside the concept of Maqashid Shariah.

The Anova Test $(\mathrm{F})$ result of the contribution of Maqashid Shariah concept to the Return on Equity (ROE) performance of Islamic banking in Indonesia indicated that the value of $\mathrm{F}$ count was 2.638. This value was higher than the $\mathrm{t}$ table value which was 2.433 . If the $\mathrm{F}$ count $>\mathrm{F}$ table, then $\mathrm{Ho}$ was rejected and $\mathrm{Ha}$ was accepted. This meant that the hypothesis in this analysis revealed that there was a contribution of the Tahdhib al-Fard, Iqamat al-Adl, and Jalb al-Maslahah variable simultaneously to the performance of Return on Equity (ROE) of Islamic banking.

Furthermore, the $\mathrm{t}$ statistic test result of the Tahdhib al-Fard variable indicator toward the performance of Return on Assets (ROA) of Islamic banking showed that one of the indicators, namely "Allocation of research \& development fund (i2x1)" had t count value of 1,888 . This value was higher than the value of t table of 1.69913, 
meaning that the Tahdhib al-Fard variable indicator contributed to the performance of Return on Assets (ROA) of Islamic banking. Moreover, for the Iqamat al-Adl variable, the $t$ count analysis result of "Equitable distribution (i1x2)" indicator was t count value of -1.858 . In addition, the indicator of "Functional distribution (murabaha \& musharakah) (i2x2)" had t count value of 1.798 . The values of $t$ count for both Iqamat al-Adl variable indicators were higher than $t$ table value; thus Ho was rejected, and $\mathrm{Ha}$ was accepted. This meant that there was a contribution of the Iqamat al$A d l$ variable indicators towards the performance of Return on Assets (ROA) of Islamic banking in Indonesia.

The next analysis was to see the contribution of the Jalb alMaslahah variable indicator to the Return on Assets (ROA) performance of Islamic banking partially. The result of the analysis revealed that the indicator of "Real sector investment (i2x3)" in the variable of Jalb al-Maslahah had $\mathrm{t}$ count value of 2.364 , this value was higher than the value of $t$ table of 1.69913. Consequently, it was concluded that Ho was rejected and $\mathrm{Ha}$ was accepted, that is, there was a contribution of the Jalb al-Maslahah variable indicator to the performance of Return on Assets (ROA) of Islamic banking in Indonesia partially.

The determination coefficient of the Maqashid Shariah concept on the performance of Return on Equity (ROE) of Sharia Commercial Banks was the R Square value of 0.397 (39.7\%). This result illustrated that the performance of Islamic banking Return on Equity (ROE) could be explained by the Maqashid Shariah concept, namely the Tahdhib alFard, Iqamat al-Adl, and Jalb alMaslahah variable, amounted to $39.7 \%$. Moreover, this meant that there were around $61.3 \%(100 \%$ $39.7 \%$ ) described by other variables other than the Maqashid Shariah concept.

The implementation of the Tahdhib al-Fard in the six Sharia Commercial Banks (SCB) was measured by three assessment indicators, namely the indicators of education and training fund allocation of Islamic banking human resources, research and development cost, and public awareness for Islamic banking. All of these assessments could be used as an achievement assessment of Islamic banking on the values of Maqashid Shariah. Omar (2008) stated that the higher Islamic banks allocated their funds for these three indicators, the better achievement of the Tahdhib al-Fard program has. This also impacted on the improvement of human resources quality and at the same time created information to the public about the objectives and products of Islamic banking. Moreover, the contribution of the Tahdhib al-Fard aspect to Islamic banking financial performance, namely Return on Assets (ROA) and Return on Equity (ROE), as indicated in the partial test was the aspect of Tahdhib al-Fard did not contribute to the performance of Return on Assets (ROA) but had a contribution to Return on Equity (ROE).

This research proved that Islamic banking in Indonesia from 
2010 to 2015 continuously reduced the fund allocation for Tahdhib alFard activities so that this did not affect its financial performance. This result was regrettable considering that Islamic banking in Indonesia had not been able to implement fundamental Islamic values (Maqashid Shariah) properly. As a result, it was recommended for Islamic banks in Indonesia to implement fundamental Islamic values consistently by increasing the allocation of education and training fund, research and development fund, and socialization funds (advertisements) in order to have a positive impact on Islamic banking financial performance.

The results of the $t$ statistic test analysis (partial) discovered that the aspect of Iqamat al-Adl (building justice) did not have a contribution to the financial performance of Islamic banking, namely Return on Assets (ROA) but had a contribution to Return on Equity (ROE). The implementation of the Iqamat al-'Adl aspect could be seen from the financing level of mudharabah and musyarakah of Islamic banking. This research showed that functional distribution indicator, namely the allocation of mudharabah and musyarakah model financing in the Iqamat al-'Adl aspect, contributed to the financial performance of Islamic banking Return on Equity (ROE); however, it did not indicate an influence on Return on Assets (ROA).

Further, the Jalb al-Malahah aspect could be analyzed from two measurement indicators, namely: the value of zakat fund allocation as the achievement of the general public maslahah and the value of real sector financing as maslahah towards the productive economy. The $\mathrm{t}$ statistic test of Jalb al-Maslahah aspect in the Maqashid Shariah concept of Islamic banking financial performance discovered that the aspect of Jalb alMaslahah did not contribute to Return on Assets (ROA) and Return on Equity (ROE) of Islamic banking in Indonesia. This analysis result also indicated that the allocation of the zakat fund did not have a contribution to financial performance; however, the real sector investment had a positive and significant contribution to Islamic banking financial performance.

The low allocation of zakat fund was the best reason to explain why the zakat fund allocation did not contribute to financial performance. The results of this research found that Islamic banking had not been able to distribute zakat optimally. The allocation of the zakat fund was the implementation of sharia banking alignments to the welfare of the community.

This research demonstrated that the role of zakat fund allocation in Islamic banking finance did not have a dominant influence to enhance the Islamic banking financial performance. Accordingly, Islamic banking must see the allocation of zakat fund not only as part of Islamic banking obligations but also could be used as a consideration to increase the profitability of Islamic banking. This was because the increase of zakat fund allocation was directly proportional to the increase of bank financial performance, and vice versa, the increase in financial 
performance would have an impact on the increase of zakat fund allocation.

\section{CONCLUSION}

The result of causality relationship test between the Maqashid Shariah concept and Islamic banking financial performance, namely Return on Assets (ROA) and Return on Equity (ROE), by using Multiple Linear Regression is the aspect of Tahdhib al-Fard, Iqamat al-'Adl, and Jalb alMaslahah in the Maqashid Shariah concept simultaneously contribute to the Return on Assets (ROA) financial performance of Islamic banking in Indonesia, with a determination coefficient (R Square) value of $34.9 \%$.

Partially, the aspect of Jalb alMaslahah has a contribution to Return on Assets (ROA) represented by the indicator of "real sector investment." Meanwhile, the aspect of Tahdhib al-Fard and Iqamat al'Adl have no contribution to the Return on Assets (ROA) of Islamic banking. The Tahdhib al-Fard, Iqamat al-'Adl, and Jalb alMaslahah aspect in the Maqashid Shariah concept simultaneously contribute to Return on Equity (ROE) of Islamic banking financial performance in Indonesia with a contribution value of $39.7 \%$. Besides, Partially, the aspect of Tahdhib al-Fard which is represented by one indicator, namely the indicator of "Allocation of research and development fund" has a contribution to Return on Equity (ROE).
Furthermore, the Iqamat al-Adl aspect has a dominant contribution compared to other aspects. The Iqamat al-Adl aspect indicators, namely "Equitable distribution" and "Functional distribution" have a contribution to Return on Equity (ROE). Moreover, the aspect of Jalb al-Maslahah also contributes to Return on Equity (ROE) represented by the indicator of "Real sector investment."

\section{REFERENCES}

Abozaid, Abdulazeem, and Asyraf Wajdi Dusuki. (2007). he challenges of realizing maqasid al-shariah in islamic banking and finance, a paper presented at the IIUM International Conference on Islamic Banking and Finance: 'Research and development: the bridge between ideals and realities' organized by IIUM Institute of Islamic Banking and Finance, Kuala Lumpur.

Adebayo, R. Ibrahim and M. Kabir Hassan. (2013). Rethical principles of Islamic financial institutions. Journal of Economic Cooperation and Development, 34, 1, 63-90.

Ahmed, Habib. (2011). Maqasid alShari'ah and Islamic financial products: a framework for assessment. ISRA International Journal of Islamic Finance, Vol. 3, Issue 1, 149-159.

Ahmed, Zainab A. and Bob Ryan. (2011). Religion and cultural dimensions of trust in the emerging financial market in Libya. International Journal of 
Behavioural Accounting and Finance, 2.3-4, 208-224.

1-Ghazali. (1937). al-Mustasfa. Cairo: al-Maktabah alTijariyyah al- Kubra.

Antonio, Muhammad Syafii, et al. (2012). An analysis of Islamic banking performance: maqashid index implementation in indonesia and Jordania. Journal of Islamic Finance, Vol. 1 No. 1, 12-19.

Asutay, Mehmet. (2007). Conceptualization of the second best solution in overcoming the social failure of Islamic banking and finance: Examining the overpowering of homoislamicus by homoeconomicus. Journal of Economics and Management 15, No. 2, 167-195.

Burton, Brian K. and Michael G. Goldsby. (2010). The moral floor: A philosophical examination of the connection between ethics and business. Journal of Business Ethics, Vol. 91, No. 1 145-154.

Dangulbi, Sani M. (2012). A conceptual model of measuring performance efficiency of islamic banks: Objectives of Islamic Law (Maqasid AlShariah) Approach. Available at SSRN 2070397.

Dow, Sheila C. (2010). Keynes on knowledge, expectations and rationality. For presentation to the Center on Capitalism and Society Conference on Microfoundations for Modern Macroeconomics, New York 19-20.

Friedman. Milton. (1970). The social responsibility of business is to increase its profits. New York Times Magazine,.

Hameed, Shahul, et al. (2004). Alternative disclosure and performance measures for islamic banks. In Second Conference on Administrative Sciences: Meeting the Challenges of the Globalization Age, King Fahd University of Petroleum \& Minerals, Dhahran, Saudi Arabia 19-21.

Hilary, Gilles dan Kai Wai Hui. (2009). Does Religion Matter in Corporate Decision Making in America?. Journal of Financial Economics 93, 3, 455-473.

Hooker, J. N. (2010). Moral implications of rational choice theories. Tepper School of Business, Carnegie Mellon University.

Houssem, M. (2012). Shari'ahbased ethical performance measurement framework. Journal Chair for Ethics and Financial Norms, 1-19.

Jahja, Adi Susilo, et al. (2012). Analisis perbandingan kinerja keuangan perbankan syariah dengan perbankan konvensional. Jurnal Ekonomi dan Bisnis, Vol.VI, No.2 141150.

Lumer, Christoph. (2010). The relevance of rational decision theory for ethics. Journal Ethical Theory And Moral Practice, 13 485-496.

Mansour. Walid, et al. (2013). Islamic banks performance and maqashid al-shariah. Paper presented to the 9th AsiaPacific Economic Association Conference Osaka, Japan, July 27-28. 
Mattingly, James E. (2004). Stakeholder salience, structural development, and firm performance: Structural and performance correlates of sociopolitical stakeholder management strategies. Journal Business Society, 43, 1 97-114.

Mayew, William J., et al. (2012). Religious social norms and corporate financial reporting. Journal of Business Finance \& Accounting 39.7-8, 845-875.

McClennen, Edward F. (2010). Rational choice and moral theory. Journal Ethic Theory Moral Prac, 13 521-540.

McWilliams, Abagail and Siegel, D. (2000). Corporate social responsibility and financial performance: Correlation or misspecification?. Strategic Management Journal, Vol. 21, No. 5 603-609.

Omar, Mustafa, M, et al. (2008). The performance measures of Islamic banking based on the maqasid framework. Paper IIUM International Accounting Conference (INTAC IV) held at Putra Jaya Marroitt, 1-17.

Rowley, Tim and Shawn Berman. (2000). A brand new brand of corporate social performance. Journal Business Society, 39, 4, 397-418.

Sakaran, Uma. (2000). Research methods for business: a skill building approach. New York: John Wiley \& Sons. 20-28.

Setiawan, Azis Budi. (2009). Kesehatan finansial dan kinerja sosial bank umum syariah di Indonesia. Paper Seminar Ilmiah Kerjasama Magister Bisnis Keuangan Islam Univ. Paramadina, Ikatan Ahli Ekonomi Islam (IAEI) Pusat dan Masyarakat Ekonomi Syariah (MES).

Surroca, Jordi and Trib, J.A. (2008). Managerial entrenchment and corporate social performance. Journal of Business Finance and Accounting, 35, 5,6 748760.

Wiranti, W. (2014). Analisis komparatif kinerja keuangan bank syariah berdasarkan income statement approach dengan value added statement pada Bank Syariah Mandiri di Indonesia. eJournal Ilmu Administrasi Bisnis, 2, 1, 30-40.

Zahrah, Muhammad Abu (1997). Ushûl al-Fiqh. Cairo: Dar alFikr al-Arabi. 